\title{
Does Vitamin D Deficiency Cause Direct Inguinal Hernia? Preliminary Results
}

\author{
Mehmet Eren Yüksel ${ }^{1} \odot$, Funda Tamer ${ }^{2} \odot$, Emine Avci ${ }^{3} \odot$
}

${ }^{1}$ Aksaray University School of Medicine, Department of General Surgery, Aksaray, Turkey

${ }^{2}$ Gazi University School of Medicine, Department of Dermatology, Ankara, Turkey

${ }^{3}$ General Directorate of Public Health, Department of Infectious Diseases, Ankara, Turkey

Mehmet Eren Yüksel, Asst. Prof. Funda Tamer, Asst. Prof. Emine Avcl, MD

\section{Correspondence:}

Asst. Prof. Mehmet Eren Yüksel Aksaray University School of Medicine, Department of General Surgery, Aksaray, Turkey Phone: +905425610755

E-mail: doctormehmeteren@yahoo.com

Received : May 06, 2019

Revised : October 07,2019

Accepted : October 20, 2019

\begin{abstract}
Purpose: Direct inguinal hernia is a protrusion of the visceral contents through the weakened part of the abdominal wall. The serum level of vitamin D has a positive correlation with muscle mass and functions. Therefore, decreased serum levels of vitamin D may facilitate direct inguinal hernia development. We aimed to compare the serum levels of vitamin $D$ in patients with direct inguinal hernia and healthy individuals.
\end{abstract}

Materials and Methods: Between April 2018 and October 2018, 30 patients with direct inguinal hernia (28 male, 2 female) and 30 healthy individuals within the control group ( 28 male, 2 female) were included in the study. Serum vitamin D levels of the participants and ultrasound findings of the patients were reviewed retrospectively.

Results: The mean serum $25(\mathrm{OH}) \mathrm{D}$ level was $23.11 \pm 8.42 \mathrm{ng} / \mathrm{mL}$ in patients and $24.77 \pm 10.67 \mathrm{ng} / \mathrm{mL}$ in healthy individuals, respectively $(\mathrm{p}=0.77)$. Serum $25(\mathrm{OH}) \mathrm{D}$ level was decreased in $27(90 \%)$ patients, and it was within normal limits in $3(10 \%)$ patients. Serum $25(\mathrm{OH}) \mathrm{D}$ level was decreased in $21(70 \%)$ healthy individuals, and it was normal in 9 (30\%) healthy individuals within the control group $(p=0.11)$.

Conclusion: The results obtained from this study revealed that the patients with direct inguinal hernia had lower serum vitamin D levels than healthy individuals. However, there was no statistically significant difference in serum vitamin D levels between patients with inguinal hernia and control group. Therefore, our hypothesis if low serum 25(OH)D levels caused direct inguinal hernia could not be proved. A larger sample group is needed for further investigation.

Keywords: Hernia, inguinal, vitamin D

\section{VITAMINI EKSIKLIĞi DiREKT INGUINAL HERNI OLUŞMASINA NEDEN OLUR MU? ÖN SONUÇLAR \\ ÖZET}

Amaç: Direkt inguinal herni, viseral içeriğin karın duvarının zayıflayan kısmından protrüde olmasıdır. Serum D vitamini düzeyi kas kitlesi ve kas fonksiyonları ile pozitif bir ilişki gösterir. Bu nedenle, düşük serum D vitamini düzeyleri direkt inguinal herni gelişmesini kolaylaştırabilir. Biz de bu çalışmada, inguinal hernisi olan hastaların ve sağlıklı bireylerin serum D vitamini düzeylerini karşılaştırmayı amaçladık.

Materyal ve Methodlar: Çalışmaya Nisan 2018 ve Ekim 2018 tarihleri arasında değerlendirilen direkt inguinal hernisi olan 30 hasta (28 erkek, 2 kadın) ve kontrol grubu içerisindeki 30 sağlıkı birey (28 erkek, 2 kadın) dâhil edilmiştir. Tüm katılımcıların serum $D$ vitamini düzeyleri ve hastaların ultrasonografi bulguları retrospektif olarak değerlendirilmiştir.

Bulgular: Hastaların ve sağlıklı bireylerin ortalama serum 25(OH)D düzeyleri sırasıyla $23,11 \pm 8,42 \mathrm{ng} / \mathrm{mL}$ ve $24,77 \pm 10,67$ $\mathrm{ng} / \mathrm{mL}$ olarak bulunmuştur $(\mathrm{p}=0,77)$. Serum $25(\mathrm{OH}) \mathrm{D}$ düzeyleri $27(\% 90)$ hastada düşük, $3(\% 10)$ hastada ise normal sınırlar içerisindeydi. Serum 25(OH)D düzeyleri kontrol grubundaki 21 (\%70) sağlıklı bireyde düşük, 9 (\%30) sağlıklı bireyde ise normal sınırlar içerisindeydi $(\mathrm{p}=0,11)$.

Sonuç: Bu çalışmadan elde edilen sonuçlar, direkt inguinal hernisi olan hastaların sağlıkı bireylere göre daha düşük serum D vitamini düzeylerine sahip olduğunu göstermiştir. Bununla birlikte, inguinal hernisi olan hastalar ile kontrol grubu arasında serum D vitamini düzeyleri açısından istatiksel olarak anlamlı bir fark yoktu. Dolayısıyla düşük serum 25(OH)D düzeylerinin direkt inguinal herni oluşmasına neden olacağı hipotezimiz kanıtlanamamıştır. İleri araştırma için daha geniş bir örneklem grubuna ihtiyaç vardır.

Anahtar sözcükler: Herni, inguinal, D vitamini 
D irect inguinal hernia represents the protrusion of visceral contents and adipose tissue through the abdominal wall (1). It has been suggested that $27 \%$ of men and $3 \%$ of women have the risk of developing an inguinal hernia during a lifetime (2). Male gender, old age, obesity, increased intraabdominal pressure, connective tissue disorders are regarded as risk factors (2). Inguinal hernia repair is one of the most common surgical procedures performed worldwide (1). Inguinal hernias can result in strangulation and obstruction due to incarceration (3).

Patients with inguinal hernia have altered levels of the enzymes of connective tissue, larger collagen degradation, disrupted collagen fiber ratio and fascia features (2). Histopathological evaluation of the structural changes in the muscle tissue of groin area in inguinal hernia specimens reveals atrophy, hyaline and fibrotic degeneration and fatty dystrophy of the myocytes (4).

Chronic pain and infertility are the long term complications of hernia repair. Low recurrence rates have been reported with mesh repair (3). In contrast, smoking increases the recurrence risk, however, it is controversial whether smoking facilitates the development of inguinal hernia or not. Smoking can lead to herniation by decreasing collagen synthesis and increasing the degradation of collagen (2).

Vitamin $D$ is an essential hormone for calcium and phosphate metabolism. However, it plays a role in various extraskeletal functions affecting approximately 2000 genes. Vitamin D is associated with cardiovascular diseases, infectious diseases, malignancies and autoimmune diseases like type 1 diabetes, systemic lupus erythematosus, rheumatoid arthritis, and inflammatory bowel disease (5). Moreover, it has been suggested that vitamin D may play a role in muscle health. Serum levels of vitamin $D$ may have a positive correlation with muscle mass and muscle functions (6). Older adults are likely to have low serum vitamin levels as a result of reduced nutritional intake, increased adipose tissue, decreased cutaneous synthesis and less time spent outside (7).

Hereby, we evaluated serum levels of vitamin D in patients with a direct inguinal hernia to investigate the role of vitamin $D$ in the etiopathogenesis of inguinal hernia.

\section{Materials and Methods}

This study included 30 patients with direct inguinal hernia and 30 healthy individuals within the control group.
Patients had unilateral (right-sided/left-sided) or bilateral inguinal hernias. All involved patients gave their informed consent statements prior to the study. Medical records, serum 25-hydroxyvitamin D (25(OH)D) levels and ultrasound findings of the participants were reviewed retrospectively between April 2018 and October 2018.

The exclusion criteria were pregnancy, hormone-replacement therapy, chemotherapy, immunosuppressive therapy, hyperparathyroidism, hyperthyroidism, intestinal malabsorption syndromes, chronic renal disease, gastric bypass surgery, vitamin and mineral supplements, eating disorders and diet restrictions.

Statistical analysis was performed using SPSS 20.0 Statistical Package Program. Descriptive statistics for categorical variables include number, percentage; the mean \pm standard deviation and the median (minimum; maximum) for the numerical variables. The chi-square test was used to compare categorical variables between healthy individuals and patient groups. Normal distribution was tested for numerical variables and non-parametric tests were used for intergroup comparisons because the values were not normally distributed. Mann-Whitney $\mathrm{U}$ test was used to compare the two independent groups. KruskalWallis test was used to compare more than two independent groups.

\section{Results}

Thirty patients with direct inguinal hernia and 30 healthy individuals within the control group were included in the study. Each group consisted of 28 (93.3\%) male and $2(6.7 \%)$ female participants. The mean age of the patients and healthy individuals were $55.63 \pm 14.68$ and $54.07 \pm 14.77$ years respectively $(p=0.66)$. The median age of the patients and healthy individuals were 55.5 (range, $32-81)$ and 55 (range, 28-79) years, respectively $(p=0.66)$.

The mean serum $25(\mathrm{OH})$ D level was $23.11 \pm 8.42 \mathrm{ng} / \mathrm{mL}$ in patients and $24.77 \pm 10.67 \mathrm{ng} / \mathrm{mL}$ in healthy individuals, respectively $(p=0.77)$ (Figure 1$)$. The median level of 25(OH)D in patients and healthy individuals were 25.05 (range, 6.79-47.95) $\mathrm{ng} / \mathrm{mL}$ and 22.42 (range, 7.89-51.30) $\mathrm{ng} / \mathrm{mL}$, respectively $(\mathrm{p}=0.77)$. Serum $25(\mathrm{OH}) \mathrm{D}$ level was decreased in 27 (90\%) patients, and it was within normal limits in $3(10 \%)$ patients. Serum $25(\mathrm{OH}) \mathrm{D}$ level was decreased in 21 (70\%) healthy individuals, and it was normal in $9(30 \%)$ healthy individuals within the control group $(p=0.11)$ (Table 1). 
A level of serum vitamin $D$ of $30 \mathrm{ng} / \mathrm{mL}$ and more is regarded as normal whereas a level of serum vitamin $D$ less than $30 \mathrm{ng} / \mathrm{mL}$ is regarded as low.

Ultrasound examination of the groin revealed right-sided inguinal hernia in 15 (25\%) patients, left-sided inguinal hernia in $10(16.7 \%)$ patients and bilateral inguinal hernia in $5(8.3 \%)$ patients.

The mean serum $25(\mathrm{OH}) \mathrm{D}$ level of the patients with right-sided inguinal hernia $(n=15)$ was $26.05 \pm 9.51 \mathrm{ng} /$

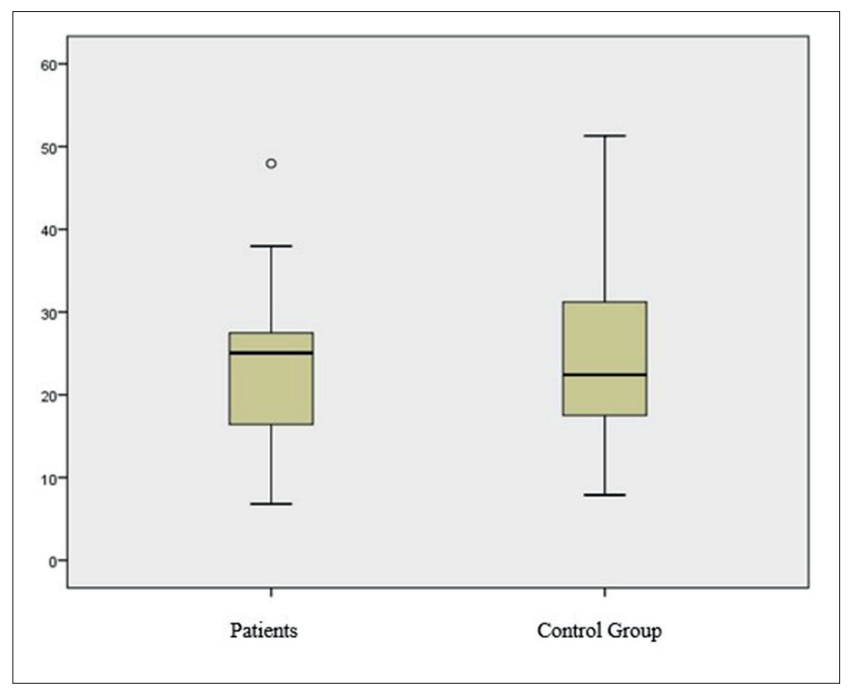

Figure 1. Distribution of serum vitamin $\mathrm{D}$ levels in patient and control groups The mean serum $25(\mathrm{OH}) \mathrm{D}$ level $(24.77 \pm 10.67 \mathrm{ng} / \mathrm{mL})$ was higher in healthy individuals when compared to patients with inguinal hernia $(23.11 \pm 8.42 \mathrm{ng} /$ $\mathrm{mL})$. The mean serum $25(\mathrm{OH}) \mathrm{D}$ level did not differ significantly between two groups $(p=0.77)$. However, serum $25(\mathrm{OH}) \mathrm{D}$ level was normal in $9(30 \%)$ healthy individuals, while only $3(10 \%)$ patients had normal levels of serum $25(\mathrm{OH}) \mathrm{D}$.
$\mathrm{mL}$. The mean serum $25(\mathrm{OH}) \mathrm{D}$ level of the patients with left-sided inguinal hernia $(\mathrm{n}=10)$ was $19.32 \pm 6.23 \mathrm{ng} / \mathrm{mL}$. The mean serum 25(OH)D level of the patients with bilateral inguinal hernia $(n=5)$ was $21.87 \pm 6.33 \mathrm{ng} / \mathrm{mL}(\mathrm{p}=0.26)$ (Figure 2). The median level of 25(OH)D in patients with the right-sided inguinal hernia was 26.65 (range, 6.79-47.95) $\mathrm{ng} / \mathrm{mL}$. The median level of $25(\mathrm{OH}) \mathrm{D}$ in patients with the left-sided inguinal hernia was 18.6 (range, 8.52-26.98) ng/ $\mathrm{mL}$. The median level of $25(\mathrm{OH}) \mathrm{D}$ in patients with the bilateral inguinal hernia was 25.37 (range, 12.94-27.94) ng/ $\mathrm{mL}(\mathrm{p}=0.26)$.

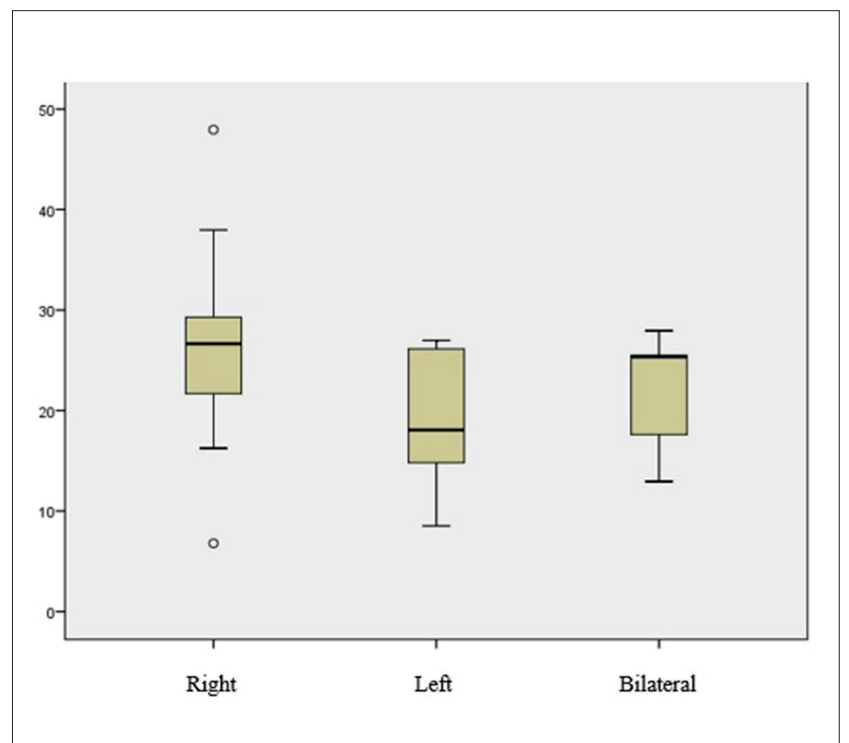

Figure 2. Distribution of serum vitamin $D$ levels in patients with inguinal hernia The mean serum 25(OH)D level of the patients with right-sided inguinal hernia, left-sided inguinal hernia and bilateral inguinal hernia were $26.05 \pm 9.51$, $19.32 \pm 6.23$ and $21.87 \pm 6.33 \mathrm{ng} / \mathrm{mL}$, respectively $(p=0.26)$.

Table 1. Characteristics and laboratory test results of the patients and control group

\begin{tabular}{|c|c|c|c|}
\hline & $\begin{array}{l}\text { Patient group } \\
\quad(n=30)\end{array}$ & $\begin{array}{l}\text { Control group } \\
\qquad(n=30)\end{array}$ & $P$ value \\
\hline Mean age (years) & $55.63 \pm 14.68$ & $54.07 \pm 14.77$ & 0.66 \\
\hline Mean 25(OH)D level (ng/mL) & $23.11 \pm 8.42$ & $24.77 \pm 10.67$ & 0.77 \\
\hline Median 25(OH)D level (ng/mL) & 25.05 (range, 6.79-47.95) & 22.42 (range, $7.89-51.30$ ) & 0.77 \\
\hline Decreased/normal 25(OH)D level $(n, \%)$ & $27(90 \%) / 3(10 \%)$ & $21(70 \%) / 9(30 \%)$ & 0.11 \\
\hline Patients with RSIH (n,\%) & $15(25 \%)$ & & \\
\hline $\begin{array}{l}\text { Patients with LSIH }(n, \%) \\
\text { Patients with BIH }(n, \%)\end{array}$ & $\begin{array}{l}10(16.7 \%) \\
5(8.3 \%)\end{array}$ & & \\
\hline $\begin{array}{l}\text { Mean 25(OH)D level of patients with } \\
\text { RSIH/LSIH/BIH }(\mathrm{ng} / \mathrm{mL})\end{array}$ & $26.05 \pm 9.51 / 19.32 \pm 6.23 / 21.87 \pm 6.33$ & & 0.26 \\
\hline $\begin{array}{l}\text { Median 25(OH)D level of patients with } \\
\mathrm{RSIH} / \mathrm{LSIH} / \mathrm{BIH}(\mathrm{ng} / \mathrm{mL})\end{array}$ & $\begin{array}{l}\quad 26.65 \text { (range, 6.79-47.95) / 18.6 } \\
\text { (range, 8.52-26.98)/ 25.37(range, 12.94-27.94) }\end{array}$ & & 0.26 \\
\hline
\end{tabular}

25(OH)D, Serum 25-hydroxyvitamin D; RSIH, right sided inguinal hernia; LSIH, left sided inguinal hernia; BIH: bilateral inguinal hernia. Serum $25(\mathrm{OH}) \mathrm{D}$ level was decreased in $27(90 \%)$ patients, and it was within normal limits in $3(10 \%)$ patients. Serum $25(\mathrm{OH}) \mathrm{D}$ level was decreased in $21(70 \%)$ healthy individuals, and it was normal in $9(30 \%)$ healthy individuals within the control group $(\mathrm{p}=0.11)$. 
Surgical repair of inguinal hernia (Lichtenstein's mesh repair) was performed in all patients without any complications.

\section{Discussion}

The layers of the abdominal wall consist of skin, subcutaneous tissue, Scarpa and Camper fascias, external oblique fascia and muscle, internal oblique fascia and muscle, transversus abdominis muscle, transversalis fascia, preperitoneal fat, and peritoneum. A weakness of any of these layers in the groin can lead to an inguinal hernia. Twenty million patients undergo surgical inguinal hernia repair all over the world annually. Surgical techniques aim to provide access to the required part of the groin through the abdominal wall. The treatment goal is defined as short recovery time, low complication rates and minimum cost (8).

The underlying mechanisms for the hernia formation still remain controversial (9). Nevertheless, increased intra-abdominal pressure has been regarded as a significant risk factor for the last 200 years. Etiological factors include collagen diseases like Marfan syndrome, Ehlers-Danlos syndrome, osteogenesis imperfecta, collagen deficiencies, chronic cough, urinary and bowel straining, heavy lifting, excess intra-abdominal fluid, intra-abdominal tumors, intra-cellular factors like increased protease activity, decrease in hydroxyproline, and increase in type III collagen (10).

A recurrent inguinal hernia is a common clinical problem after hernia surgery. The exact cause for recurrence for inguinal hernias remains unclear. However, risk factors for recurrence following inguinal hernia repair operation are regarded as female sex, connective tissue composition and degradation, direct inguinal hernia, recurrent inguinal hernia, smoking and surgical methods (11).

Estradiol and testosterone are known to play a role in the regulation of skeletal muscle mass. Lower abdominal muscle tissue consists of oblique and transverse skeletal muscles. The increased incidence of inguinal hernia is associated with skeletal muscle atrophy and fibrosis in the inguinal region in the elderly. Recently, Zhao et al. reported that shift from androgen to estradiol action results in hernia formation leading to fibrosis in lower abdominal muscle tissue. Estradiol which is produced by aromatase from testosterone constitutes estrogen in men. Aromatase activity of the muscle tissue and also inguinal hernia incidence rise with aging. An increase in estradiol to testosterone ratio in men by aging may play a role in inguinal hernia development leading to fibrosis and atrophy in the lower abdominal muscle (9).
Vitamin D has an impact on muscle mass and muscle functions via its receptors in the muscle tissue. 25-hydroxyvitamin $D$ reduces muscle degradation. Therefore, it has been suggested that serum concentrations of $25(\mathrm{OH})$ $D$ may be associated with muscle mass and strength (12). However, the mechanisms of the effect of vitamin D on muscle strength and function have not been identified clearly yet (13).

Mieszkowski et al. investigated the effect of Nordic walking and vitamin $D$ on the performance of 42 women over the age of 60 . They reported beneficial effects of vitamin D supplementation on increased muscle mass, muscle strength and improved postural control (12). Patients with severe chronic obstructive pulmonary disease (COPD) usually have weakened muscles, cachexia or sarcopenia. Carson et al. investigated the changes in vitamin status and its relation between fat-free mass and muscle strength in patients with COPD. Carson et al. reported a positive correlation between muscle strength and $25(\mathrm{OH})$ D concentration, independent of age, sex and smoking status. Vitamin D supplementation was advised/recommended to maintain optimal 25(OH)D concentrations advised to protect musculoskeletal health (14). Nejatinamini et al. reported a correlation between plasma $25(\mathrm{OH}) \mathrm{D}$ levels with skeletal muscle mass and the tendency to lose muscle in head and neck cancer patients with low $25(\mathrm{OH})$ D concentrations (15).

The main reason for the inguinal hernia development is the degenerative changes of the lower abdominal muscles that weaken the muscle strength. Myocyte atrophy, fibrosis and fatty degeneration in the internal inguinal ring area and the abdominal wall have been demonstrated previously (9). As the weakness in the connective tissue or muscles of the patient leads to an inguinal hernia, we suggest that decreased vitamin $D$ levels may be associated with the development of a direct inguinal hernia. In our study, the patients with direct inguinal hernia had lower serum 25(OH)D levels (23.11 \pm 8.42$)$ than in healthy individuals (24.77 \pm 10.67$)$. There was no statistically significant difference in vitamin $D$ levels in both groups $(p=0.77)$. However, low vitamin $D$ levels were more frequent in patients with inguinal hernia compared to healthy individuals. Twenty-seven (90\%) patients with inguinal hernia had serum vitamin $D$ levels under 30 $\mathrm{ng} / \mathrm{mL}$, while $21(70 \%)$ healthy individuals had serum vitamin D levels under $30 \mathrm{ng} / \mathrm{mL}$. The risk of vitamin D deficiency increases by age as in inguinal hernia development $(7,9)$. Our study demonstrated that low serum 
$25(\mathrm{OH}) \mathrm{D}$ levels are common in elderly patients with direct inguinal hernia.

\section{Conclusion}

Decreased levels of vitamin D may facilitate the development of an inguinal hernia. Our results revealed that low

\section{References}

1. Köckerling F, Simons MP. Current concepts of inguinal hernia repair. Visc Med 2018;34:145-50. [CrossRef]

2. Öberg S, Andresen K, Rosenberg J. Etiology of inguinal hernias: A comprehensive review. Front Surg 2017;4:52. [CrossRef]

3. Jenkins JT, O'Dwyer PJ. Inguinal hernias. BMJ 2008;336:269-72. [CrossRef]

4. Amato G, Agrusa A, Romano G, Salamone G, Gulotta G, Silvestri $F$, Bussani $R$. Muscle degeneration in inguinal hernia specimens. Hernia 2012;16:327-31. [CrossRef]

5. Muscogiuri G. Vitamin D. Past, present and future perspectives in the prevention of chronic diseases. Eur J Clin Nutr 2018;72:1221-5. [CrossRef]

6. Beaudart C, Buckinx F, Rabenda V, Gillain S, Cavalier E, Slomian J, et al. The effects of vitamin $D$ on skeletal muscle strength, muscle mass, and muscle power: A systematic review and meta-analysis of randomized controlled trials. J Clin Endocrinol Metab 2014;99:433645. [CrossRef]

7. Meehan $M$, Penckofer S. The role of vitamin $D$ in the aging adult. J Aging Gerontol 2014;2:60-71. [CrossRef]

8. Miller HJ. Inguinal hernia: Mastering the anatomy. Surg Clin North Am 2018;98:607-21. [CrossRef]

9. Zhao H, Zhou L, Li L, Coon V J, Chatterton RT, Brooks DC, et al. Shift from androgen to estrogen action causes abdominal muscle fibrosis, atrophy, and inguinal hernia in a transgenic male mouse model. Proc Natl Acad Sci U S A 2018;115:E10427-36. [CrossRef] serum vitamin D levels are more common in patients with direct inguinal hernia compared to healthy individuals. However, there was no statistically significant difference between the two groups. Therefore, the vitamin D status of a larger sample group should be evaluated in order to reach a definitive conclusion.

10. O'Rourke MG, O'Rourke TR. Inguinal hernia: Etiology, diagnosis, post-repair pain and compensation. ANZ J Surg 2012;82:201-6. [CrossRef]

11. Burcharth J, Pommergaard HC, Bisgaard T, Rosenberg J. Patientrelated risk factors for recurrence after inguinal hernia repair: $A$ systematic review and meta-analysis of observational studies. Surg Innov 2015;22:303-17. [CrossRef]

12. Mieszkowski J, Niespodziński B, Kochanowicz A, Gmiat A, Prusik K, Prusik K, et al. The effect of Nordic walking training combined with vitamin $D$ supplementation on postural control and muscle strength in elderly people -a randomized controlled trial. Int J Environ Res Public Health 2018;15:1951. [CrossRef]

13. Agostini D, Donati Zeppa S, Lucertini F, Annibalini G, Gervasi M, Ferri Marini C, et al. Muscle and bone health in postmenopausal women: role of protein and vitamin $D$ supplementation combined with exercise training. Nutrients 2018;10:1103. [CrossRef]

14. Carson EL, Pourshahidi LK, Madigan SM, Baldrick FR, Kelly MG, Laird E, et al. Vitamin D status is associated with muscle strength and quality of life in patients with COPD. A seasonal prospective observation study. Int J Chron Obstruct Pulmon Dis 2018;13:2613-22. [CrossRef]

15. Nejatinamini S, Debenham BJ, Clugston RD, Mawani A, Parliament M, Wismer WV, Mazurak V. Poor vitamin status is associated with skeletal muscle loss and mucositis in head and neck cancer patients. Nutrients 2018;10:1236. [CrossRef] 